\title{
Cobalt nanoparticles induce lung injury, DNA damage and mutations in mice
}

Rong Wan ${ }^{1,2 \dagger}$, Yiqun $\mathrm{Mo}^{2 \dagger}$, Zhenyu Zhang ${ }^{3 \dagger}$, Mizu Jiang ${ }^{2,4}$, Shichuan Tang $^{5}$ and Qunwei Zhang ${ }^{2,5,6^{*}}$ (D)

\begin{abstract}
Background: We and other groups have demonstrated that exposure to cobalt nanoparticles (Nano-Co) caused oxidative stress and inflammation, which have been shown to be strongly associated with genotoxic and carcinogenic effects. However, few studies have reported Nano-Co-induced genotoxic effects in vivo. Here, we propose that NanoCo may have high genotoxic effects due to their small size and high surface area, which have high capacity for causing oxidative stress and inflammation.

Methods: $g$ pt delta transgenic mice were used as our in vivo study model. They were intratracheally instilled with $50 \mu \mathrm{g}$ per mouse of Nano-Co. At day 1, 3, 7 and 28 after exposure, bronchoalveolar lavage (BAL) was performed and the number of neutrophils, CXCL1/KC level, LDH activity and concentration of total protein in the BAL fluid (BALF) were determined. Mouse lung tissues were collected for H\&E staining, and Ki-67, PCNA and $\mathrm{\gamma}-\mathrm{H} 2 \mathrm{AX}$ immunohistochemical staining. 8-OHdG level in the genomic DNA of mouse lungs was determined by an OxiSelect ${ }^{\text {TM }}$ Oxidative DNA Damage ELISA Kit, and mutant frequency and mutation spectrum in the gpt gene were also determined in mouse lungs at four months after Nano-Co exposure by 6-TG selection, colony PCR, and DNA sequencing.

Results: Exposure of mice to Nano-Co $(50 \mu \mathrm{g}$ per mouse) resulted in extensive acute lung inflammation and lung injury which were reflected by increased number of neutrophils, CXCL1/KC level, LDH activity and concentration of total protein in the BALF, and infiltration of large amount of neutrophils and macrophages in the alveolar space and interstitial tissues. Increased immunostaining of cell proliferation markers, Ki-67 and PCNA, and the DNA damage marker, $Y-H 2 A X$, was also observed in bronchiolar epithelial cells and hyperplastic type II pneumocytes in mouse lungs at day 7 after Nano-Co exposure. At four months after exposure, extensive interstitial fibrosis and proliferation of interstitial cells with inflammatory cells infiltrating the alveolar septa were observed. Moreover, Nano-Co caused increased level of 8OHdG in genomic DNA of mouse lung tissues. Nano-Co also induced a much higher mutant frequency as compared to controls, and the most common mutation was G:C to T:A transversion, which may be explained by Nano-Co-induced increased formation of 8-OHdG.

Conclusion: Our study demonstrated that exposure to Nano-Co caused oxidative stress, lung inflammation and injury, and cell proliferation, which further resulted in DNA damage and DNA mutation. These findings have important implications for understanding the potential health effects of nanoparticle exposure.
\end{abstract}

Keywords: Cobalt nanoparticles, DNA damage, Histone H2AX phosphorylation, 8-hydroxy-2'-deoxyguanosine, Mutation, Oxidative stress, Titanium dioxide nanoparticles

\footnotetext{
*Correspondence: Qunwei.Zhang@louisville.edu

${ }^{\dagger}$ Equal contributors

${ }^{2}$ Department of Environmental and Occupational Health Sciences, School of

Public Health and Information Sciences, University of Louisville, 485 E. Gray

Street, Louisville, KY 40202, USA

${ }^{5}$ Beijing Municipal Institute of Labor Protection, Beijing, People's Republic of

China

Full list of author information is available at the end of the article
}

(c) The Author(s). 2017 Open Access This article is distributed under the terms of the Creative Commons Attribution 4.0 International License (http://creativecommons.org/licenses/by/4.0/), which permits unrestricted use, distribution, and reproduction in any medium, provided you give appropriate credit to the original author(s) and the source, provide a link to the Creative Commons license, and indicate if changes were made. The Creative Commons Public Domain Dedication waiver (http://creativecommons.org/publicdomain/zero/1.0/) applies to the data made available in this article, unless otherwise stated. 


\section{Background}

The application of nanotechnological products in human activities has been rapidly increasing in the past decade largely due to the unique properties of engineered nanoparticles. Of utmost interest are metal nanoparticles and their biological effects, since these nanoparticles have been widely used in cosmetics, medicine, electronics and industry. Cobalt is a transition and magnetic metal; cobalt nanoparticles (Nano-Co) have special characteristics, such as high surface area due to their small size, high magnetism and unique catalytic properties, etc. They are widely used in industrial applications such as magnetic tape, chemical catalysis, gas sensing equipment, coating, and light absorbance, as well as in medical biotechnology such as magnetic resonance imaging [1-3], and an experimental cancer treatment called magnetic hyperthermia, which uses the heat that nanoparticles produced when they are placed in an alternative magnetic field to kill cancer cells [2, 4, 5]. Thus, occupational and non-occupational exposure to metal nanoparticles is growing, and their potential health effects cannot be ignored. In fact, we and other in vitro studies have shown that exposure to cobalt or cobalt-containing nanoparticles caused oxidative stress, inflammation, and DNA damage [6-11]. In addition, some metal nanoparticles may have genotoxic and carcinogenic effects due to the chemical nature of the metal. Certain metal particles can generate reactive oxygen species (ROS) that can cause oxidative stress and DNA damage. For example, a couple of studies have shown that exposure to magnetite or carbon nanoparticles induced DNA mutations in the mouse lungs [12, 13]. Although some studies have shown the potential genotoxic effects of some nanomaterials, their mechanisms are still unclear. In this study, we selected Nano-Co as a 'model' metal nanoparticle because of its industrial interest and wide biological and medical applications. We examined its potential genotoxic effects and the possible mechanisms involved. Investigating the genotoxic effects and measuring the different types of DNA damage, such as gene mutation and DNA strand break formation, are important parts of evaluation and assessment of potential carcinogens.

It is well known that one initiating pathogenic effect of oxidative stress is inflammation, which can cause DNA damage and genotoxicity [14-18]. The association between genotoxicity and cancer is well known. For example, the carcinogenic effects of ionizing radiation, UV radiation and many chemical carcinogens are based on their ability to cause DNA damage and consequent gene mutation $[15,18,19]$. There are several excellent reviews regarding metals, oxidative stress and cancer [15-17]. It is generally accepted that excessive generation of ROS overwhelms the antioxidant defense system, causing oxidation of cellular biomolecules [18]. Free radicals cause oxidative modifications in DNA, including strand breaks and base oxidation. Among oxidative DNA damage products, 8hydroxy-2'-deoxyguanosine $(8-\mathrm{OHdG})$ is probably the most studied, due to its relative ease of measurement and pre-mutagenic potential $[15,16,18,20,21]$. Elevated 8OHdG has been noted in numerous tumors, strongly implicating such damage in the etiology of cancer [15, 21]. Although uptake of nanoparticles by cells depends on material, size, shape, surface charge, and so on [22], previous studies have shown that metal nanoparticles may be able to penetrate into cells through passive diffusion, receptormediated endocytosis, and clathrin- or caveolae-mediated endocytosis, and subsequently enter the nucleus through diffusion across the nuclear membrane, or via the nuclear pore complexes. They may also become enclosed in the nucleus by a change following mitosis as the nuclear membrane dissolves during cell division and then reforms in each daughter [23-25]. If nanoparticles enter the nucleus, then direct interaction between nanoparticles and DNA or DNA-related proteins could lead to physical damage to the genetic material $[24,26]$.

Our and other previous in vitro studies have shown that exposure to cobalt nanoparticles or cobalt alloys such as cobalt-chromium alloy nanoparticles, caused DNA damage and cell transformation, and that ROS generation and oxidative stress were involved in those effects [10, 11, 27-30]. However, previous studies were conducted in cultured cells, and confirmation from animal experiments which are more relevant to human exposure is required. Therefore, the aim of present study is to explore the genotoxic effects of Nano-Co in vivo by using guanine phosphoribosyltransferase (gpt) delta transgenic mice which carry about 80 copies of the transgene, lambda EG10 DNA, on each chromosome 17 $[31,32]$. When rescued phages are used to infect $E$. coli expressing Cre recombinase, they are converted into plasmids harboring the chloramphenicol $(\mathrm{Cm})$ resistance and gpt genes. Gpt mutants are selected using plates containing $\mathrm{Cm}$ and 6-thioguanine (6-TG). And mutant frequency and mutant sequence analysis of gpt gene in the lung tissues from mice exposed to Nano-Co were evaluated. In addition, $\gamma-\mathrm{H}_{2} \mathrm{AX}$ immunostaining and 8OHdG level in the genomic DNA in the lung tissues from mice exposed to Nano-Co were also determined.

\section{Methods \\ Metal nanoparticles}

Nano-Co and Nano-TiO 2 with a mean diameter of $20 \mathrm{~nm}$ and $28 \mathrm{~nm}$ were provided by INABTA and Co., Ltd., Vacuum Metallurgical Co., Ltd., Japan. The characterization of these nanoparticles was described in our previous studies [11,33]. Briefly, the diameter by transmission electron microscopy (TEM) is 10-40 nm for Nano-Co and 10-60 nm for Nano- $-\mathrm{TiO}_{2}$, and the 
specific surface area is $47.9 \mathrm{~m}^{2} / \mathrm{g}$ for Nano-Co and $45.0 \mathrm{~m}^{2} / \mathrm{g}$ for Nano- $\mathrm{TiO}_{2}$. Nano-Co is composed of $85-$ $90 \%$ metal cobalt and $10-15 \% \mathrm{Co}_{3} \mathrm{O}_{4} ; \mathrm{Nano}^{-\mathrm{TiO}_{2}}$ is composed of $90 \%$ anatase and $10 \%$ rutile. The size of particles and agglomerates in physiological saline was $260 \mathrm{~nm}$ for Nano-Co and $280 \mathrm{~nm}$ for Nano- $\mathrm{TiO}_{2}$, measured by dynamic light scattering (DLS). Nano-Co and Nano- $\mathrm{TiO}_{2}$ were dispersed in physiological saline and ultrasonicated for $10 \mathrm{~min}$ prior to each experiment. The solubility of Nano-Co and Nano- $\mathrm{TiO}_{2}$ in $1 \times \mathrm{PBS}$ and artificial alveolar fluid [34] was measured as previously reported $[11,35]$. In brief, five $30 \mathrm{mg}$ samples of NanoCo or Nano- $\mathrm{TiO}_{2}$ were suspended in $30 \mathrm{ml}$ of $1 \times \mathrm{PBS}$ or artificial alveolar fluid, respectively. After shaking for $48 \mathrm{~h}$ in a water bath at $37{ }^{\circ} \mathrm{C}$, the samples were ultrasonicated for $30 \mathrm{~min}$ and then centrifuged at 12,000 g for $20 \mathrm{~min}$. The supernatants were collected to determine the concentration of cobalt or titanium ion by inductively coupled plasma-atomic emission spectrometry (ICP-AES). The results were shown in Table 1.

\section{Animals}

The gpt delta transgenic mice were originally obtained from Dr. Takehiko Nohmi at the National Institute of Health Science in Japan, which were established as described [30,31,33]. These mice carry about 80 copies of transgene, lambda EG10 DNA, on chromosome 17 in a C57BL/6 J background. The lambda EG10 DNA carries the gpt gene of $E$. coli. The enzyme encoded by gpt gene, guanine phosphoribosyltransferase, catalyzes phosphoribosylation of guanine, which is the obligatory step for the incorporation of guanine to DNA. This enzyme also phosphoribosylates 6-thioguanine (6-TG), which is toxic to cells when it is incorporated into DNA, thus allowing the selection of gpt mutants by 6-TG. In addition, the coding region of the gpt gene is $456 \mathrm{bp}$, which is convenient for the identification of mutation by DNA sequencing. The mice were bred and housed in an air-conditioned room (temperature of $20 \pm 2{ }^{\circ} \mathrm{C}$, relative humidity of $60 \pm 10 \%$ ) with a 12-h light and 12-h dark cycle environment, and with free access to food and water. Animal use was reviewed and approved by the University of Louisville Institutional Animal Care and Use Committee.

\section{Exposure of mice to metal nanoparticles}

Female or male mice, 8-12 weeks old, weighted $\sim 20$ $22 \mathrm{~g}$ for female and $\sim 25-28 \mathrm{~g}$ for male, were exposed to

Table 1 lons released from metal nanoparticles in PBS and artificial alveolar fluid

\begin{tabular}{lll}
\hline Metal & PBS $(\mathrm{ppm})$ & Artificial alveolar fluid $(\mathrm{ppm})$ \\
\hline Nano-Co & $10.81 \pm 0.62$ & $16.85 \pm 1.68$ \\
Nano-TiO $_{2}$ & $<1.00$ & $<1.00$ \\
\hline
\end{tabular}

nanoparticles by intratracheal instillation as described previously [33, 36, 37]. The intratracheal instillation model was selected instead of an inhalation study because the former is an easy and reliable method to identify nanoparticle toxicity and compare responses to different particle types [38]. Mice were grouped randomly $(n=4 \sim 8)$, but the ratio of female to male mice in each group was kept to $\sim 1: 1$. Mouse neck skin was opened by a small midline incision and the trachea was isolated. $50 \mu \mathrm{L}$ of physiological saline contained $50 \mu \mathrm{g}$ of Nano-Co or Nano- $\mathrm{TiO}_{2}$ was instilled intratracheally by a syringe with a $28 \mathrm{G} 1 / 2$ needle, followed by $100 \mu \mathrm{L}$ of air to ensure deposition into the lower airways. The skin was then closed with a monofilament nylon suture. Control mice were injected with physiological saline alone. At day 1 after exposure, mice lost $6.4 \pm 1.8 \%$ of body weight for Nano-Co-treated group, but only $0.5 \pm 1.3 \%$ for $\mathrm{Nano}-\mathrm{TiO}_{2}$-treated group and no body weight loss was observed for control group. At $3 \sim 4$ days after Nano-Co exposure, the mouse body weight started to bounce back. Only $1.0 \pm 1.0 \%$ of body weight loss was observed at day 7 after Nano-Co exposure, and the body weight was slowly recovering until the end of the experimental period. The mice in the control and $\mathrm{Nano}-\mathrm{TiO}_{2}-$ treated groups grew normally. No mice died during the experimental period. The mice were sacrificed at day 1 , 3,7 and 28 , or four months after instillation of metal nanoparticles.

\section{Preparation of bronchoalveolar lavage fluid (BALF)}

The mice were sacrificed by overdose injection of tribromoethanol into the abdominal cavity and severing of abdominal aorta. The trachea was clearly visualized after skin and soft tissue dissection, and a 20 gauge cannula was inserted into the trachea. $0.8 \mathrm{~mL}$ of ice-cold 1xPBS containing $0.4 \mathrm{mM}$ EDTA was used to lavage the lungs bilaterally. The lavage fluid was retrieved by gentle massage. The procedure was repeated another four times. The initially collected lavage fluid sample was centrifuged at $1600 \mathrm{rpm}$ for 5 mins at $4^{\circ} \mathrm{C}$. The supernatant was collected and stored at $-80^{\circ} \mathrm{C}$ for subsequent analysis of biochemical markers. The cells in the BALF were pooled. The number of total cells was counted under a microscope using a hemacytometer. The cell differential count was evaluated on a cytospin slide stained with Giemsa May-Grünwald stains (Sigma-Aldrich, St. Louis, MO). A minimum of 400 cells were examined under a light microscope.

\section{Biochemical evaluation of BALF}

The lactate dehydrogenase (LDH) activity in the BALF was measured by a LDH Cytotoxicity Detection Kit (TaKaRa Bio, Inc., Japan). The concentration of total protein in the BALF was determined by the Bradford 
method using Bio-Rad Protein Assay (Bio-Rad, Hercules, $\mathrm{CA})$. The level of chemokine (C-X-C motif) ligand 1 (CXCL1)/keratinocyte chemoattractant (KC) was assessed by a Mouse CXCL1/KC PicoKine ${ }^{\mathrm{ma}}$ ELISA Kit (Boster Biological Technology, Pleasanton, CA).

\section{Histological examination}

Mouse lung tissues were fixed in 10\% neutral buffered formalin, dehydrated stepwise through ascending series of alcohol solutions and, finally, degreased in xylene. The tissues were then embedded in paraffin, sectioned at $5 \mu \mathrm{m}$ by a microtome and stained with hematoxylin and eosin (HE) stains (Fisher, Fair Lawn, NJ).

\section{Immunohistochemistry}

The expressions of Ki-67, PCNA and $\gamma$-H2AX were evaluated by immunohistochemistry in paraffin-embedded lung sections by a VECTASTAIN Elite ABC Kit (Vector Laboratories, Burlingame, $\mathrm{CA}$ ). In brief, lung tissues were deparaffinized, hydrated, and immersed in $0.3 \% \mathrm{H}_{2} \mathrm{O}_{2}$ in methanol for $30 \mathrm{~min}$ to inactivate endogenous peroxidase. For antigen retrieval, tissues were incubated in $10 \mathrm{mM}$ sodium citrate $(\mathrm{pH} 6.0)$ with $0.05 \%$ Tween- 20 at $95{ }^{\circ} \mathrm{C}$ for $30 \mathrm{~min}$. Non-specific binding of antibodies was blocked by incubating tissues with Blocking Serum for $30 \mathrm{~min}$ at room temperature. Tissues were then incubated with antiKi-67 (Thermo Fisher, Waltham, MA), anti-PCNA (Santa Cruz, Dallas, TX), or anti- $\gamma-\mathrm{H} 2 \mathrm{AX}$ (Millipore, Billerica, MA) antibody overnight at $4{ }^{\circ} \mathrm{C}$. After being washed, tissues were subsequently incubated with biotinylated secondary antibody for $1 \mathrm{~h}$, streptavidin-conjugated horseradish peroxidase for another $1 \mathrm{~h}$, and 3, 3diaminobenzidine (DAB) until desired stain intensity develops, with the washing between each step. Sections were counterstained with hematoxylin, mounted and examined under a light microscope. For quantitation of Ki-67, PCNA and $\gamma-\mathrm{H} 2 \mathrm{AX}$ staining in mouse lung sections, numbers of both immunostaining positive and negative cells on three randomly selected high-power fields were counted and combined for each mouse. At least 600 cells per mouse were examined, and the percentage of immunostaining positive cells was calculated for each mouse (\% positive cells $=$ number of positive cells $/$ number of total cells $\times 100)$ [39].

\section{Trichrome staining}

Masson's Trichrome for Connective Tissue kit (Electron Microscopy Sciences, Hatfield, PA) was used according to the manufacturer's instructions with minor modifications. Lung sections were deparaffinized, hydrated to distilled water, and mordanted in Bouin's Fixative at room temperature overnight to intensify the final coloration. After being washed, tissues were stained in Weigert's Iron Hematoxylin Working solution for $4 \mathrm{~min}$.
After the wash, tissues were stained in Biebrich ScarletAcid Fuchsin for $4 \mathrm{~min}$. After rinsing with deionized water, tissues were treated with Phosphomolybdic Acid/ Phosphotungstic Acid for $15 \mathrm{~min}$, followed by staining in Aniline Blue Solution for 15 min. After briefly being differentiated in $1 \%$ Acetic Acid, tissues were dehydrated through alcohol, cleared in xylene, and mounted.

\section{Determination of 8-OHdG level}

8-OHdG level was determined in the genomic DNA of mouse lung tissues. Genomic DNA was purified by using a QIAamp DNA Mini kit (QIAGEN, Germantown, MD) according to the manufacturer's instructions with minor modification. Briefly, 10-25 mg of lung tissues were cut into small pieces and lysed in $180 \mu \mathrm{L}$ of Buffer ATL and $20 \mu \mathrm{L}$ of proteinase $\mathrm{K}$ at $56^{\circ} \mathrm{C}$ water bath until the tissue was completely lysed. $4 \mu \mathrm{L}$ of $100 \mathrm{mg} / \mathrm{mL}$ RNase A was added to degrade the RNA. $200 \mu \mathrm{L}$ of Buffer AL was added to the solution and the tube was incubated at $70^{\circ}$ $\mathrm{C}$ for $10 \mathrm{~min}$. After being mixed with $200 \mu \mathrm{L}$ of $100 \%$ ethanol, the solution was applied to a QIAamp Mini spin column. After being washed, the genomic DNA was dissolved in $200 \mu \mathrm{L}$ of nuclease-free distilled water and its concentration was determined by a spectrophotometer. 8-OHdG level in genomic DNA was determined by OxiSelect $^{\text {tix }}$ Oxidative DNA Damage ELISA Kit (Cell Biolabs, San Diego, CA) according to the manufacturer's instructions, and expressed as the amount of $8-\mathrm{OHdG}(\mathrm{pg})$ in one microgram $(\mu \mathrm{g})$ of genomic DNA.

\section{Determination of gpt mutant frequency}

Genomic DNA was extracted from mouse lung tissues using a RecoverEase DNA Isolation Kit (Stratagene, La Jolla, CA), and Lambda EG10 phages were rescued using Transpack Packaging Extract (Stratagene) according to the manufacturer's instruction. The gpt mutations were detected as described previously [12, 31, 40-42]. Briefly, E.coli YG6020 expressing Cre recombinase (provided by Dr. Nohmi) was infected with the rescued phages and spread on M9 salt plates containing chloramphenicol $(\mathrm{Cm})$ and 6-thioguanine (6-TG). The plate was incubated at $37^{\circ} \mathrm{C}$ for $72 \mathrm{~h}$, which enables selection of colonies harboring a plasmid carrying genes for chloramphenicol acetyltransferase (CAT) and a mutated gpt. Those $(\mathrm{Cm}+6-\mathrm{TG})$-resistant colonies, which contain a mutated gpt, were counted. The 6-TG-resistant phenotype of the colony was again confirmed by streaking E.coli cells on the $(\mathrm{Cm}+6-\mathrm{TG})$ agar plate and the plate was incubated at $37^{\circ} \mathrm{C}$ for $72 \mathrm{~h}$. To obtain the total number of Cm-resistant colonies, E.coli YG6020 was infected with an aliquot of rescued phage suspension and spread on M9 salt plates containing chloramphenicol $(\mathrm{Cm})$ only, but without 6-TG. The plate was also incubated at $37^{\circ} \mathrm{C}$ for $72 \mathrm{~h}$. Mutant frequency was calculated 
by dividing the number of colonies growing on $(\mathrm{Cm}+6$ TG) agar plate by the number on $\mathrm{Cm}$ agar plate as reported previously [12, 31, 40-42].

Colony PCR and DNA sequencing analysis of gpt mutants Colony PCR was performed to amplify a 739 bp DNA fragment containing the mutated gpt gene in the $(\mathrm{Cm}+6$ TG)-resistant colonies as described previously [41, 43]. Briefly, colonies on the $(\mathrm{Cm}+6-\mathrm{TG})$ agar plates were picked and transferred to PCR tubes containing $25 \mu \mathrm{L}$ of sterile water. After being incubated at $99^{\circ} \mathrm{C}$ for $5 \mathrm{~min}$ to lyse the cells and denature DNases, the tube was centrifuged to remove cell debris, and $5 \mu \mathrm{L}$ of the solution was transferred to a new PCR tube for PCR amplification. PCR was performed on a Mastercycler (Eppendorf, Hauppauge, NY) for 35 cycles, each cycle using sequentially $94^{\circ}$ $\mathrm{C}$ for $30 \mathrm{~s}, 58^{\circ} \mathrm{C}$ for $30 \mathrm{~s}$, and $72^{\circ} \mathrm{C}$ for $1 \mathrm{~min}$. The forward primer was: $5^{\prime}$-TACCACTTTATCCCGCGTCAGG-3'. The reverse primer was: 5'-ACAGGGTTTCGCT CAGGTTTGC-3'. The amplified PCR products were checked by agarose gel electrophoresis, and sent to DNA core facility at University of Louisville for sequencing. The sequencing primers were either 5'-GAGGCAGTGCG TAAAAAGAC-3' or 5'-CTATTGTAACCCGCCTGA AG-3' as described previously [41].

\section{Statistical analysis}

Data were expressed as the mean \pm SE. Differences among groups were evaluated by one-way analysis of variance (ANOVA) followed by Dunnett's t-test or Bonferroni $\mathrm{t}$-test. If necessary, transformation (logarithmic or square root) of data was used to achieve normally distributed data. If a $p$ value was less than 0.05 , a difference was considered statistically significant. Statistical analyses were carried out using SigmaPlot 13.0 software (Systat Software, Inc., San Jose, CA).

\section{Results}

\section{Cellular and biochemical constituents in BALF}

To investigate whether exposure to metal nanoparticles caused lung inflammation and lung injury, the cellular and biochemical constituents in BALF obtained from mice exposed to metal nanoparticles at different doses and time points were evaluated. Our results showed that intratracheal instillation of $50 \mu \mathrm{g}$ per mouse of Nano-Co caused severe acute inflammatory response and lung injury, which was reflected by a marked increase in the total number of neutrophils, CXCL1/KC level, LDH activity and concentration of total protein in BALF obtained from mice at as early as day 1 after exposure (Fig. 1a-d). These parameters were maintained at a higher level at day 3 and day 7 after Nano-Co exposure, but declined and returned toward control levels by day 28 (Fig. 1a-d). There was a dose-related increase in these parameters when mice were exposed to 50 and $100 \mu \mathrm{g}$ per mouse of Nano-Co (Data not shown). However, exposure to Nano- $\mathrm{TiO}_{2}$ only caused a slight increase in the number of neutrophils and CXCL1/KC level at day 1 after exposure, but both returned to control levels at day 3 after exposure and beyond (Fig. 1ab). Nano- $\mathrm{TiO}_{2}$ exposure did not have any effects on the $\mathrm{LDH}$ activity and the concentration of total protein in the BALF (Fig. 1c-d).

\section{Histopathology}

In order to observe the histopathological changes in the lungs, $H \& E$ staining was performed on the lung sections collected from mice after metal nanoparticle exposure. In the control mice, which were instilled with physiological saline, normal lung parenchymal structures were observed (Fig. 2a \& e). Instillation of Nano-Co induced severe acute lung inflammation at as early as day 1 after exposure, as evident by an increase in the influx of neutrophils (data not shown). At day 7 after exposure, infiltration of a large number of neutrophils and macrophages into the alveolar space and interstitial tissues, focal alveolar epithelial cell hyperplasia, and thickening of the alveolar septa were observed (Fig. 2c \& d). At 4 months after instillation of Nano-Co, extensive interstitial fibrosis and infiltration of inflammatory cells into the alveolar space and interstitial tissues were observed in the mouse lungs (Fig. 2g). In the thickened alveolar septa, bronchiolization of the alveoli which was characterized by replacement of alveolar epithelial cells with bronchiolar-type epithelium (arrows in Fig. 2g), micropapillomatosis, and emphysematous changes were also observed (Fig. 2g). The Nano-Co-induced lung interstitial fibrosis was further confirmed by Masson's trichrome staining, which showed an increase in the collagen deposition and proliferation of interstitial cells in the lung tissues (Fig. 2h). In contrast, Nano- $\mathrm{TiO}_{2}$ instillation only caused none or a mild inflammatory response in the mouse lungs, and there was no obvious fibrotic response in the lungs at 4 months after Nano$\mathrm{TiO}_{2}$ exposure (Fig. 2b \& f).

\section{Immunohistochemical staining for cell proliferation markers}

The expression of Ki-67 and PCNA, genes associated with cell proliferation, was determined in the lung sections by immunohistochemical staining. Our results showed that both Ki-67 and PCNA positive staining were located in the nucleus. The Ki-67-positive $(33.8 \pm 6.5 \%)$ or PCNA-positive (20.6 $\pm 4.5 \%)$ cells were significantly increased at day 7 after Nano-Co exposure, as compared to that in the control or Nano- $\mathrm{TiO}_{2}$-treated group (Fig. $3 \mathrm{~h} \mathrm{\&} \mathrm{i).} \mathrm{In} \mathrm{the} \mathrm{control} \mathrm{or} \mathrm{Nano-} \mathrm{TiO}_{2}$-treated group, only a few Ki-67-positive (Control: $7.9 \pm 2.0 \%$, 


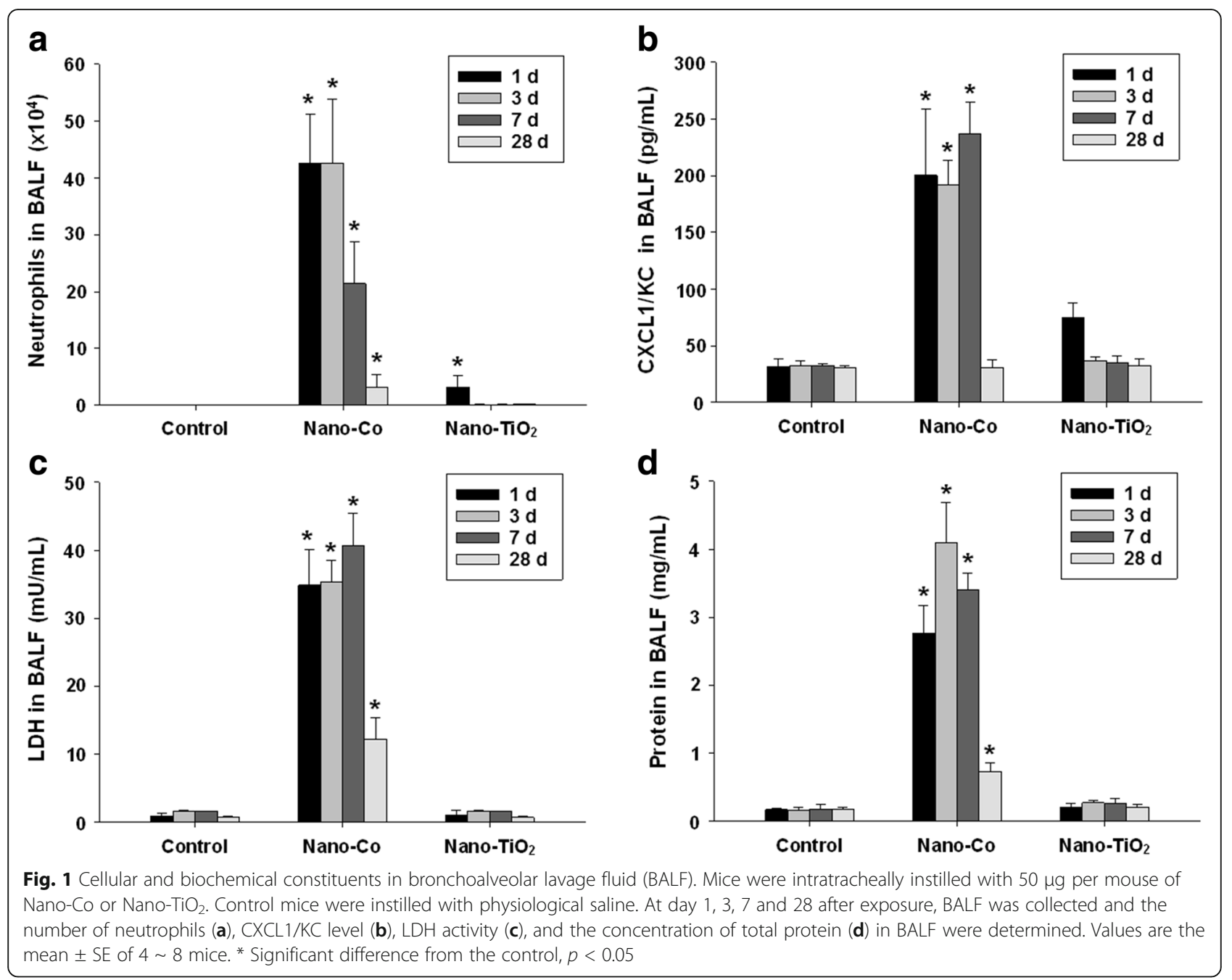

Nano- $\mathrm{TiO}_{2}: 8.7 \pm 2.1 \%$ ) (Fig. $3 \mathrm{~b} \&$ ess) or PCNApositive (Control: $5.7 \pm 1.6 \%$, Nano- $\mathrm{TiO}_{2}: 6.3 \pm 1.8 \%$ ) (Fig. 3c \& f) cells were observed. By 4 months after instillation, Nano-Co still caused increase in the number of Ki-67-positive (11.7 $\pm 1.7 \%)$ or PCNA-positive $(10.8 \pm 2.3 \%)$ cells as compared to the control or Nano$\mathrm{TiO}_{2}$-treated group, but much less than that at day 7 after Nano-Co exposure (Fig. 3k \& l).

\section{Immunohistochemical staining for DNA damage marker}

$\mathrm{H}_{2} \mathrm{AX}$ phosphorylation at Ser139 correlates very closely with each double-strand DNA break (DSB), therefore, phospho- $\mathrm{H}_{2} \mathrm{AX}\left(\gamma-\mathrm{H}_{2} \mathrm{AX}\right)$ is a sensitive marker for DNA damage and can be used to assess the effects and timing of DNA damage-inducing and DNA repair agents $[44,45]$. In the present study, in order to examine the potential genotoxic effects of metal nanoparticles, $\gamma-\mathrm{H}_{2} \mathrm{AX}$ immunostaining was evaluated in lung tissues from mice exposed to metal nanoparticles. At day 7 after instillation, the lungs from Nano-Co-treated mice showed a significant increase in $\gamma-\mathrm{H}_{2} \mathrm{AX}$-positive nuclei as compared to the physiological saline-instilled control group $(15.3 \pm 3.5 \%$ vs. $1.3 \pm 0.3 \%$, $p<0.01$ ) (Fig. $4 \mathrm{~b} \& \mathrm{f}$ ). Nano- $\mathrm{TiO}_{2}$-treated mice demonstrated a slight but not significant increase in $\gamma-\mathrm{H}_{2} \mathrm{AX}$-positive nuclei $(1.9 \pm 0.4 \%)$, less pronounced compared to the Nano-Co-treated group (Fig. 4d). At 4 months after instillation, Nano-Co still caused an increase in $\gamma-\mathrm{H}_{2} \mathrm{AX}$-positive nuclei as compared with the control and $\mathrm{Nano}-\mathrm{TiO}_{2}-$ treated mice (Data not shown).

\section{8-OHdG level in the lung tissues}

The level of 8-OHdG, a biomarker of oxidative DNA damage caused by reactive oxygen species (ROS), in the lung tissues obtained from mice 4 months after Nano$\mathrm{Co}$ and $\mathrm{Nano}-\mathrm{TiO}_{2}$ treatment was determined by ELISA. Our results showed that the level of 8-OHdG was 79.4 \pm 3.4 pg per $\mu \mathrm{g}$ of genomic DNA in the Nano-Co-treated group, which was significantly higher than that in the control group (40.6 $\pm 3.9 \mathrm{pg}$ per $\mu \mathrm{g}$ of genomic DNA) 

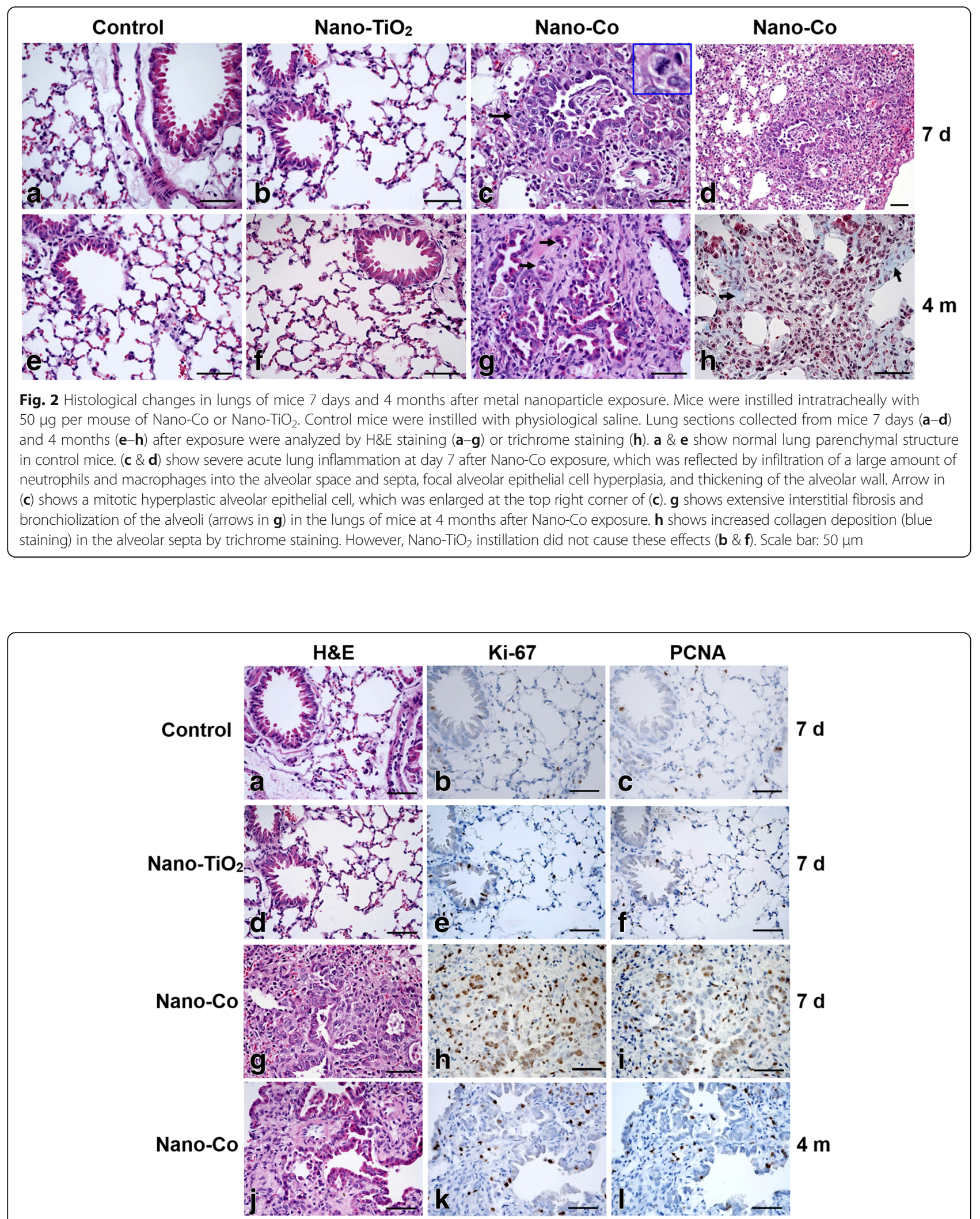

Fig. 3 Increased Ki-67 and PCNA expression in mouse lungs after Nano-Co exposure. Mice were instilled intratracheally with $50 \mu \mathrm{g}$ per mouse of Nano-Co or Nano- $\mathrm{TiO}_{2}$. Control mice were instilled with physiological saline. Lung sections collected from mice 7 days $(\mathbf{a}-\mathbf{i})$ and 4 months $(\mathbf{j}-\mathbf{I})$ after exposure were analyzed by immunohistochemistry staining. Scale bar: $50 \mu \mathrm{m}$ 


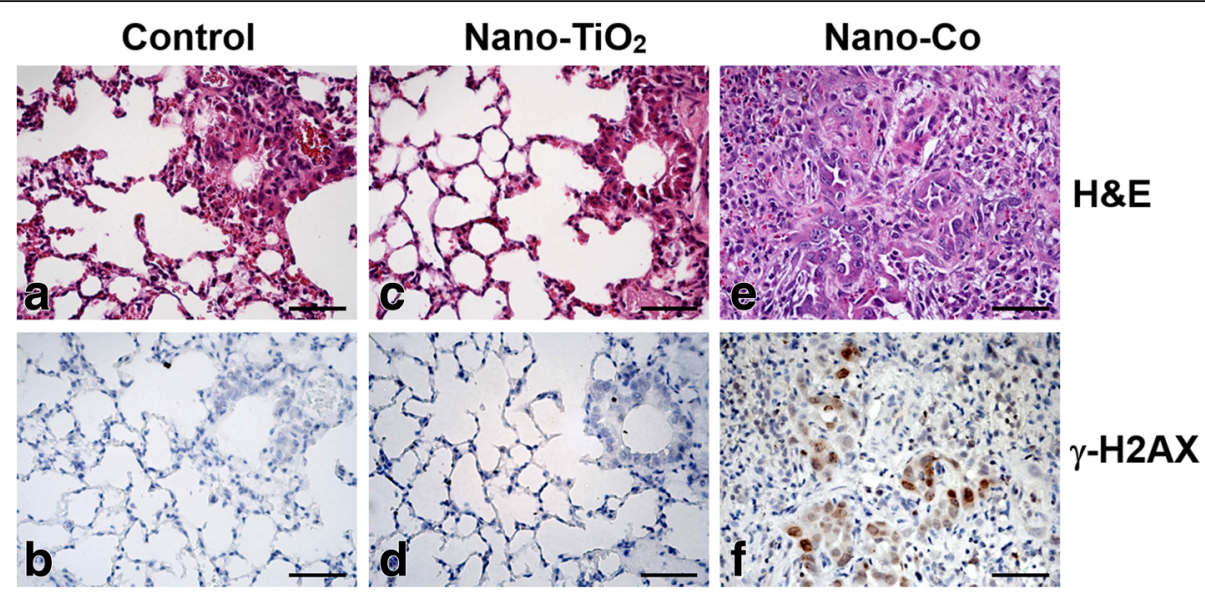

Fig. 4 Increased $y-H 2 A X$ immunostaining in mouse lungs 7 days after Nano-Co exposure. Mice were instilled intratracheally with 50 $\mu \mathrm{g}$ per mouse of

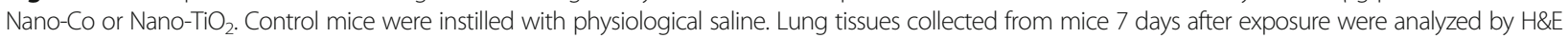
staining (a, c, e) and $\mathrm{\gamma}-\mathrm{H} 2 \mathrm{AX}$ immunohistochemistry staining (b, d, f). Scale bar: $50 \mu \mathrm{m}$

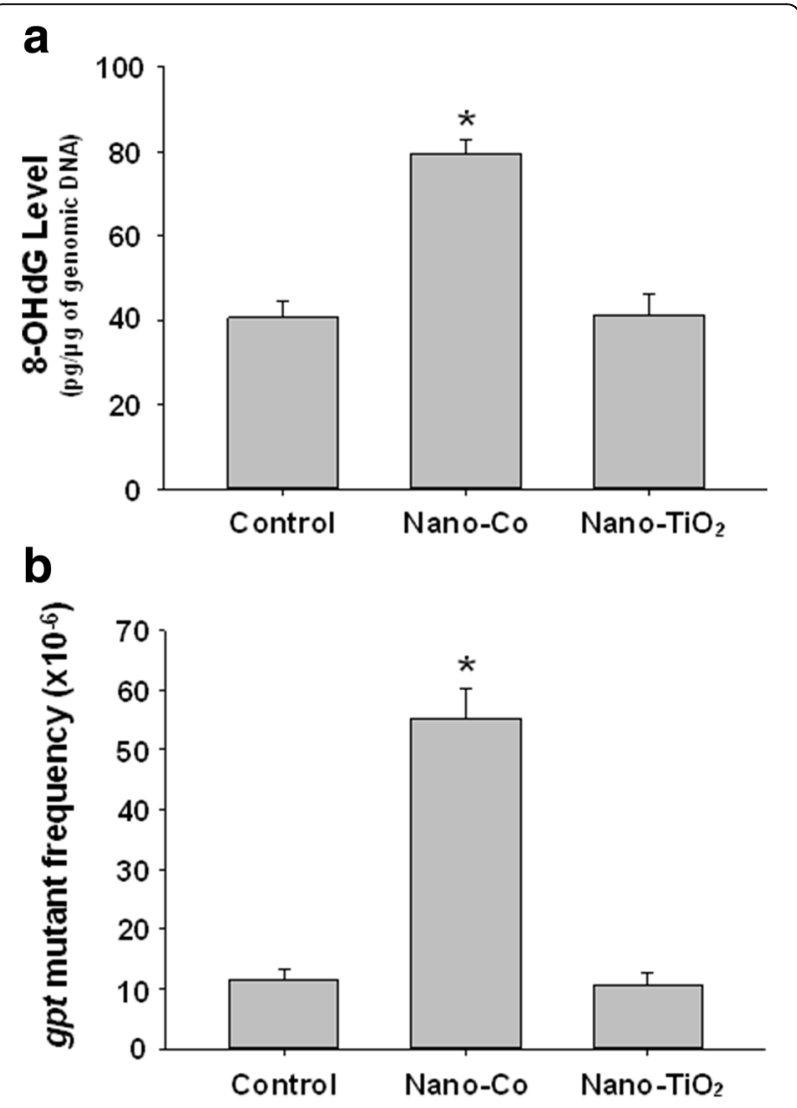

Fig. 5 8-OHdG level (a) and gpt mutant frequency (b) in the genomic DNA of lungs from mice exposed to metal nanoparticles. Mice were instilled intratracheally with $50 \mu \mathrm{g}$ per mouse of Nano-Co or $\mathrm{Nano}-\mathrm{TiO}_{2}$. Control mice were instilled with physiological saline. Lung tissues were collected four months after exposure. Data are mean \pm SE of $4 \sim 6$ mice. ${ }^{*} p<0.05$ vs. Control and in the Nano- $\mathrm{TiO}_{2}$-treated group $(41.3 \pm 4.7 \mathrm{pg}$ per $\mu \mathrm{g}$ of genomic DNA) (Fig. 5a).

gpt mutant frequency after metal nanoparticle instillation To determine the mutagenic effects of metal nanoparticles, gpt delta transgenic mice were exposed to Nano-Co or Nano- $\mathrm{TiO}_{2}$ at a dose of $50 \mu \mathrm{g}$ by single intratracheal instillation. At 4 months after exposure, mice were sacrificed and gpt mutations in the lungs of mice were analyzed as described in the Materials and Methods section. Table 2 and Fig. 5b showed the mutant frequencies (MFs) of $g p t$ genes in the lungs. The background MF of lungs was $11.6 \pm 1.8 \times 10^{-6}$. MFs in the lungs induced by Nano-Co were increased by 4.8 -fold as compared with physiological saline-instilled animals. However, exposure to $\mathrm{Nano}-\mathrm{TiO}_{2}$ did not cause significant increase in MFs in the lungs.

\section{Mutation spectrum induced by metal nanoparticles}

To examine the mutational characteristics induced by metal nanoparticles, 6-TG resistant gpt mutants were sequenced and analyzed. 62 independent 6-TG resistant mutants derived from Nano-Co, 38 from Nano- $\mathrm{TiO}_{2}$, and 19 from physiological saline instilled mice were identified. Classes of mutations found in the gpt gene were listed in Table 3. Base substitutions predominated with both metal nanoparticle-induced and spontaneous cases. No A:T to T:A and G:C to C:G transversions were detected in physiological saline-instilled control group, indicating that these types of mutations were rare events in the spontaneous mutations. However, G:C to A:T transition appears a common event in the spontaneous mutations. Interestingly, $\mathrm{G}: \mathrm{C}$ to $\mathrm{T}: \mathrm{A}$ transversion significantly increased in Nano-Co-treated group as compared with the control or Nano- $\mathrm{TiO}_{2}$-treated group, suggesting 
Table 2 Mutant frequency (MF) of gpt gene in the lungs of control and metal nanoparticle-exposed mice

\begin{tabular}{|c|c|c|c|c|c|}
\hline Treatment & Sex & No. of rescued colony & No. of mutant & $\operatorname{MF}\left(\times 10^{-6}\right)$ & Average of MF \pm SE $\left(\times 10^{-6}\right)$ \\
\hline \multirow[t]{4}{*}{ Control } & $F$ & 477,000 & 5 & 10.5 & $11.6 \pm 1.8$ \\
\hline & $\mathrm{F}$ & 540,000 & 9 & 16.7 & \\
\hline & M & 229,500 & 2 & 8.7 & \\
\hline & M & $1,429,500$ & 15 & 10.5 & \\
\hline \multirow[t]{6}{*}{ Nano-Co } & $\mathrm{F}$ & 397,500 & 20 & 50.3 & $55.2 \pm 5.0^{*}$ \\
\hline & $\mathrm{F}$ & 684,750 & 27 & 39.4 & \\
\hline & $\mathrm{F}$ & 408,000 & 22 & 53.9 & \\
\hline & M & 415,500 & 20 & 48.1 & \\
\hline & M & 236,250 & 17 & 72.0 & \\
\hline & M & 311,000 & 21 & 67.5 & \\
\hline \multirow[t]{5}{*}{ Nano- $\mathrm{TiO}_{2}$} & $\mathrm{~F}$ & 775,500 & 13 & 16.8 & $10.7 \pm 1.9$ \\
\hline & $\mathrm{F}$ & 798,000 & 10 & 12.5 & \\
\hline & M & $1,117,500$ & 7 & 6.3 & \\
\hline & M & 423,000 & 3 & 7.1 & \\
\hline & M & 451,500 & 5 & 11.1 & \\
\hline
\end{tabular}

Mice were instilled intratracheally with $50 \mu \mathrm{g}$ per mouse of Nano-Co or Nano-TiO ${ }_{2}$. Control mice were instilled with physiological saline. Lung tissues were collected four months after exposure. ${ }^{*} p<0.05$ vs. Control

Nano-Co exposure can cause G:C to T:A transversion. Other types of mutations, including A:T to $\mathrm{G}: \mathrm{C}$ transition, A:T to C:G transversion, deletions and insertions, were not significantly observed in both nanoparticletreated and control groups.

\section{Discussion}

Cobalt compounds (metal, salts, oxides, and alloys) are widely used in various industrial, medical and military applications. Exposure to cobalt and its compound

Table 3 Summary of gpt mutations in the lungs of control and metal nanoparticle-exposed mice

\begin{tabular}{|c|c|c|c|c|c|c|}
\hline \multirow{2}{*}{$\begin{array}{l}\text { Type of mutation } \\
\text { in gpt }\end{array}$} & \multicolumn{2}{|c|}{ Control } & \multicolumn{2}{|c|}{ Nano-Co } & \multicolumn{2}{|c|}{ Nano- $\mathrm{TiO}_{2}$} \\
\hline & No. & $\%$ & No. & $\%$ & No. & $\%$ \\
\hline \multicolumn{7}{|l|}{ Transition } \\
\hline$G: C$ to $A: T$ & 6 & 31.6 & 14 & 22.6 & 13 & 34.2 \\
\hline$A: T$ to $G: C$ & 2 & 10.5 & 1 & 1.6 & 6 & 15.8 \\
\hline \multicolumn{7}{|l|}{ Transversion } \\
\hline G:C to T:A & 6 & 31.6 & 38 & 61.3 & 11 & 28.9 \\
\hline$G: C$ to $C: G$ & 0 & 0 & 1 & 1.6 & 0 & 0 \\
\hline A:T to T:A & 0 & 0 & 1 & 1.6 & 0 & 0 \\
\hline$A: T$ to $C: G$ & 2 & 10.5 & 2 & 3.2 & 3 & 7.9 \\
\hline Deletions & 1 & 5.3 & 1 & 1.6 & 1 & 2.6 \\
\hline Insertions & 2 & 10.5 & 2 & 3.2 & 3 & 7.9 \\
\hline Others & 0 & 0 & 2 & 3.2 & 0 & 0 \\
\hline Total & 19 & 100 & 62 & 100 & 38 & 100 \\
\hline
\end{tabular}

Mice were instilled intratracheally with $50 \mu \mathrm{g}$ per mouse of Nano-Co or Nano$\mathrm{TiO}_{2}$. Control mice were instilled with physiological saline. Lung tissues were collected four months after exposure particles can cause pulmonary fibrosis, interstitial pneumonitis and asthma [46-50]. Cobalt compounds are listed as probable or possible human carcinogens by IARC [47]. Chronic inhalation exposure to cobalt metal and cobalt sulfate caused lung cancer in rats and mice, as well as systemic tumors in rats [47-50]. Cobalt nanoparticles (Nano-Co) have been widely used in the industries, for example, as an alloying element in super alloys and magnetic and hard-metal alloys, as pigments in the glass and ceramics industries, as catalysts in the oil and chemical industries, as paint and printing ink driers, and as trace metal additives for agricultural and medical uses $[1,2,5]$. Therefore, the use of Nano-Co has grown in the last decades in many areas, requiring the scientific community access their toxicological, genotoxic and carcinogenic potential. Nano-Co may have an unpredictable impact on human health, since traditional toxicological knowledge, based on data derived from materials in their bulk form, is not applicable in the nano-size scale. We and other previous studies have shown that exposure to Nano-Co caused lung inflammation in the rats, and Nano-Co induced more severe lung inflammation than standard-sized $(5 \mu \mathrm{M})$ cobalt particles [33, 37]. In addition, exposure to Nano-Co caused DNA damage and genotoxic effects in hepatocarcinoma cells, lung adenocarcinoma cells (A549), fibroblasts, bronchial epithelial cells (BEAS-2B) [11, 28, 50-52]. However, previous studies on DNA damage and genotoxic effects of Nano-Co were limited to in vitro studies. Only one study was found to focus on the genotoxicity of cobalt ferrite nanoparticles in the mouse liver, in which they demonstrated that exposure to cobalt ferrite nanoparticles 
caused increased expression of critical genes related to oxidative stress, apoptosis, DNA damage and cell damage [53]. However, no in vivo study was found to focus on the genotoxicity of Nano-Co in lungs. Our present study investigated whether exposure to metal nanoparticles, such as Nano-Co or Nano- $\mathrm{TiO}_{2}$, resulted in lung inflammation, DNA damage and DNA mutation in the mice by using gpt delta transgenic mice.

Although exposure to some metal nanoparticles, such as $\mathrm{TiO}_{2}$, has been identified as an occupational workplace hazard by the National Institutes of Occupational Safety and Health [54], exposure limits for cobalt nanoparticles remain undefined. Daily occupational exposures likely vary, as it is extremely difficult to predict an accurate exposure given the variability in dust generation and ventilation among worksites. Therefore, it is difficult to estimate what a relevant cobalt nanoparticle dosage or concentration should be for experimental models. The existing exposure limits for cobalt metal and ionic cobalt are difficult to translate to cobalt nanoparticle exposure; ionic cobalt is soluble in physiological fluids and cell culture buffers, and exposure modality would experience different physiological effects than exposure to a solid (non-soluble) cobalt nanoparticles. Previous studies used $10 \mathrm{mM}$ cobalt chloride $\left(\mathrm{CoCl}_{2}\right)$ in $25 \mu \mathrm{L}$ volume to treat mice by oropharyngeal aspiration for 5 days on, 2 days off, and another 5 days on. This cobalt concentration corresponds to $60 \mu \mathrm{g}$ daily exposure per mouse $[55,56]$. The doses of metal nanoparticles we used in our in vivo model (50 $\mu \mathrm{g}$ per mouse) is much lower than the doses used in a previous study with cobalt oxide nanoparticle (Nano-CoO) exposure [57]. In that study, the investigators reported that inhalation of Nano- $\mathrm{CoO}$ at $10 \mathrm{mg} / \mathrm{m}^{3}$ (low dose) or $30 \mathrm{mg} / \mathrm{m}^{3}$ (high dose) for a duration of $6 \mathrm{~h} /$ day for 4 consecutive days, induced lung injury. For a mouse of $25 \mathrm{~g}$ in size, assuming the respiratory rate is $\sim 163$ per minute, the tidal volume is $\sim 0.15 \mathrm{ml}$, and the respiratory deposition is $\sim 40 \%$, the mouse would inhaled about $352 \mu \mathrm{g}$ (low dose) and $1056 \mu \mathrm{g}$ (high dose) of Nano$\mathrm{CoO}$, and $141 \mu \mathrm{g}$ (low dose) and $423 \mu \mathrm{g}$ (high dose) of Nano-CoO would deposit in the lungs. If taking into account the mass of $\mathrm{Co}$ in the $\mathrm{CoO}$, there were $111 \mu \mathrm{g}$ (low dose) and $333 \mu \mathrm{g}$ (high dose) of Co deposited. The particles inhaled into the lungs could accumulate over time. Accidental exposure to metal nanoparticles at the workplace also cannot be ignored. There were no reports found about accidental Nano-Co exposure, however, there was a report about accidental exposure to nickel nanoparticles [58]. In that report, a worker was accidentally exposed to $\sim 1 \mathrm{~g}$ of nickel nanoparticles during his $90 \mathrm{~min}$ of operating the process. He died from acute respiratory distress syndrome. Therefore, the dose we used in this study was not unreasonable, although using lower doses of Nano-Co in our future studies will boost our findings.
Analysis of cellular damage and biochemical profile of BALF after exposure to pulmonary toxin is a useful method for determining the inflammatory response and injury of lungs $[59,60]$ : it can be used to assess lung inflammation and injury induced by various particles including nanoparticles [33, 36, 37]. For example, LDH is a cytoplasmic enzyme that released extracellularly by damaged cells. Therefore, the LDH activity in BALF reflects the degree of damage to cells and tissues [33, 61, 62]. Accumulation of neutrophils and macrophages in the lungs are key events in the inflammatory response to inhaled particles [60]. We have performed dose- and time-response studies to evaluate the pulmonary toxic effects of metal nanoparticles. Our results showed that Nano-Co caused severe acute lung inflammation which was reflected by increased number of neutrophils in BALF obtained from mice at day 1, 3, and 7 after exposure to $50 \mu \mathrm{g}$ of Nano-Co. This was accompanied by cell damage, as shown by increased LDH activity and total protein concentration in the BALF. Exposure to NanoCo also caused a significant increase in CXCL1/KC level in BALF. CXCL1/KC is a neutrophil chemokine that is known to play an important role in neutrophil recruitment in a variety of direct and indirect lung injury models including sepsis, pancreatitis, and ventilatorinduced lung injury [63]. Therefore, the increased CXCL1/KC level in the BALF may exacerbate Nano-Coinduced pulmonary inflammatory response by recruiting and activating neutrophils in the lungs through movement of circulating leukocytes to the lungs. Nano-Coinduced lung inflammation was further confirmed by histopathological examination, which revealed an influx of a large amount of neutrophils and macrophages into the pulmonary parenchyma after Nano-Co treatment. Macrophages are believed to be among the first and primary cell types that process nanoparticles, mediating host inflammatory and immunological biological responses. Our current results and the results from previous intratracheal instillation and inhalation studies in rats $[37,64]$ demonstrated that exposure to Nano-Co induced severe and persistent pulmonary inflammation, even at a low mass doses. This kind of persistent inflammation is consistent with particles of high pathogenicity such as quartz [61] and Nano-Ni [33, 38]. Instillation of bolus doses of non-pathogenic particles, such as Nano$\mathrm{TiO}_{2}$ caused only transient inflammation that resolved in a few days post-instillation [33].

Oxidative stress is considered to be an important mechanism for particle-induced health effects. Exposure to some types of nanoparticles induce oxidative stress in cells, and activation of oxidative stress-responsive transcription factors such as NF-kB and AP-1, together with the depletion of antioxidant defenses, can lead to the release of pro-inflammatory cytokines [24]. It is generally 
accepted that oxidative stress eventually causes DNA damage, which plays an important role in the development of carcinogenesis $[15,16,21] .8-\mathrm{OHdG}$ is a representative oxidative product of guanine and a highly mutagenic lesion that causes mispairing of 8-OHdG with deoxyadenosine (dA). It is a good marker for oxidative stress induced DNA damage [21]. The major problem associated with the measurement of oxidative DNA damage is the possibility of artifactual formation of DNA oxidative products during the isolation of DNA and during the analysis of 8-OHdG. However, it is important to note that, even if an oxidation occurs during derivatization, the differences in the levels of 8-OHdG between the control and the Nano-Co-treated groups observed in our study should not be artifactual, since the samples were treated in an identical fashion. Our results showed that exposure of mice to Nano-Co, but not Nano- $\mathrm{TiO}_{2}$, caused increased levels of 8-OHdG in genomic DNA of lungs, suggesting that Nano-Co-induced oxidative stress may be involved in Nano-Co-induced DNA damage in vivo.

The repair mechanisms for a specific type of DNA damage, such as double-strand DNA breaks (DSBs), involve the phosphorylation of $\mathrm{H} 2 \mathrm{AX}(\gamma-\mathrm{H} 2 \mathrm{AX})$ [44]. $\gamma$ H2AX was originally identified as an early event after the direct formation of DSBs by ionizing radiation [65]. It is now also considered to occur after the indirect formation of DSBs caused by the collision of the replication forks at sites of DNA damage including DNA adducts, single strand breaks (SSBs) and crosslinking, and the repair of the damage [45]. It was reported that $\gamma$ - $\mathrm{H} 2 \mathrm{AX}$ can be generated following the exposure of cells to various environmental factors and agents such as cigarette smoke, polycyclic aromatic hydrocarbons (PAHs), benzene metabolites, etc. [66, 67]. Therefore, studies using $\gamma$-H2AX might help to clarify the genotoxicity of exposure to various metal nanoparticles. Previous studies showed that the genotoxic potential of various nanoparticles as determined by $\gamma-\mathrm{H} 2 \mathrm{AX}$ quantification in in vitro experiments was different with exposure to alumina $\left(\mathrm{Al}_{2} \mathrm{O}_{3}\right)$ ceramic or cobalt-chromium metal nanoparticles, carbon nanotubes, and silica [68, 69]. Our previous studies have shown that $\gamma-\mathrm{H} 2 \mathrm{AX}$ is a sensitive marker for DNA damage induced by Nano-Co in vitro [11]. In this study, we found that $\gamma-\mathrm{H} 2 \mathrm{AX}$-positive nuclei were significantly increased in the lungs from mice exposed to even one single dose of Nano-Co, as compared to mice exposed to $\mathrm{Nano}-\mathrm{TiO}_{2}$ or physiological saline control. Nano-Co-induced DNA damage may be due to Nano-Co-induced oxidative stress and persistent inflammation in the lungs. Nanoparticles are not as readily phagocytized by alveolar macrophages as larger particles and can penetrate much more rapidly through the epithelium to interstitial tissues, which may result in persistent or progressive lung inflammation. Continued inflammation has been reported in an animal exposure model using asbestos and silica, thus persistent inflammation is an important feature in the formation of irreversible chronic lesions [70, 71]. Our experiments revealed that exposure to Nano-Co caused persistently increased numbers of neutrophils and 8-OHdG in the lungs. Therefore, Nano-Co-induced DNA damage in vivo might occur through a secondary genotoxic mechanism associated with inflammation and involving oxidative stress.

One method to assess the proliferative activity of cells is the immunohistochemical detection of cell cyclespecific antigens. For example, Ki-67 and PCNA proteins are standard markers of proliferation that are commonly used to assess the growth fraction of a cell population. Previous studies showed that the presence of the Ki-67 antigen in the nuclei of cells in all phases of the cell cycle, whereas it was not expressed in quiescent or resting cells in the G0 phase [72]. This feature makes this protein an excellent marker for determining the growth fraction of a given cell population [73-75]. In addition, the expression of $\mathrm{Ki}-67$ is affected by external factors such as nutrient deprivation, which could lead to underestimation of the number of cycling cells [76]. Another widely used marker, PCNA, is a less specific proliferation marker because of its redundant role in DNA repair. Thus, immunohistochemical detection of PCNA may not only detect actively dividing cells, but also those in the process of DNA repair [77]. PCNA plays important roles in the metabolism of nucleic acid. Its main function is in DNA replication, but it is also involved in DNA excision repair, cell cycle control, chromatin assembly, and RNA transcription [78]. Our present study has demonstrated that Nano-Co-treated animals exhibited a significantly elevated proliferation at day 7 after treatment. Although the proliferation decreased at 4 months after exposure, mouse lungs still exhibited a significantly increased number of Ki-67-positive or PCNA-positive cells.

Our results clearly showed that exposure to Nano-Co caused cell proliferation and DNA damage in the mice. Proliferation is an important prerequisite for manifestation of the genomic mutations. To determine whether exposure to metal nanoparticles caused mutagenic effects on the lungs, gpt gene mutations were determined and analyzed. We found that Nano-Co demonstrated mutagenicity in the gpt delta transgenic mouse system. The MFs of gpt gene were significantly increased in the lungs of gpt delta transgenic mice with exposure to Nano-Co, but not to Nano- $\mathrm{TiO}_{2}$ or to physiological saline. To explore the mechanisms involved in the NanoCo-induced increase in MFs, we analyzed the mutation spectra using a PCR-direct sequencing method. The 
most prominent mutation type induced by Nano-Co was G:C to T:A transversion (38/62, $61.3 \%)$, which was only $31.6 \%(6 / 19)$ in physiological saline-treated control

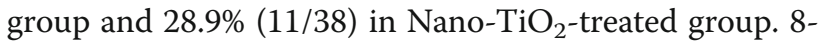
OHdG contributes to G:C to T:A transversion upon DNA replication [79]. 8-OHdG is one of the multiple oxidative damages induced in DNA by $\mathrm{OH}$. [80, 81]. This lesion represents $30-50 \%$ of the total base modification products induced by $\mathrm{OH}$-producing models and therefore is considered a 'fingerprint' of $\mathrm{OH}$. attack on DNA [82]. Our previous in vitro and current in vivo studies showed that exposure to Nano-Co caused reactive oxygen species (ROS) generation and DNA damage, including the increased 8-OHdG level [11]. Transition metals including iron $(\mathrm{Fe})$, copper $(\mathrm{Cu})$, chromium $(\mathrm{Cr})$, vanadium $(\mathrm{V})$, and silica $(\mathrm{Si})$ are involved in $\mathrm{ROS}$ generation via mechanisms such as Haber-Weiss and Fentontype reactions [83, 84]. Since cobalt has similar chemical properties to iron, it is reasonable to propose Fenton like mechanisms for the production of ROS by cobalt. In fact, Nano-Co has been reported to induce oxidative stress $\left(\mathrm{O}_{2} \cdot-\right.$ and $\left.\mathrm{OH} \cdot\right)$ via Fenton-type reaction [85]. Nano-Co also caused accumulation of macrophages and leucocytes in the lungs which may also generate ROS $[33,37]$. Fig. 6 is a schematic diagram showing the involvement of Nano-Co-induced oxidative stress in the Nano-Co-induced increased G:C to T:A transversion.

\section{Conclusions}

Taken together, our study demonstrated that exposure to Nano-Co caused oxidative stress, lung inflammation

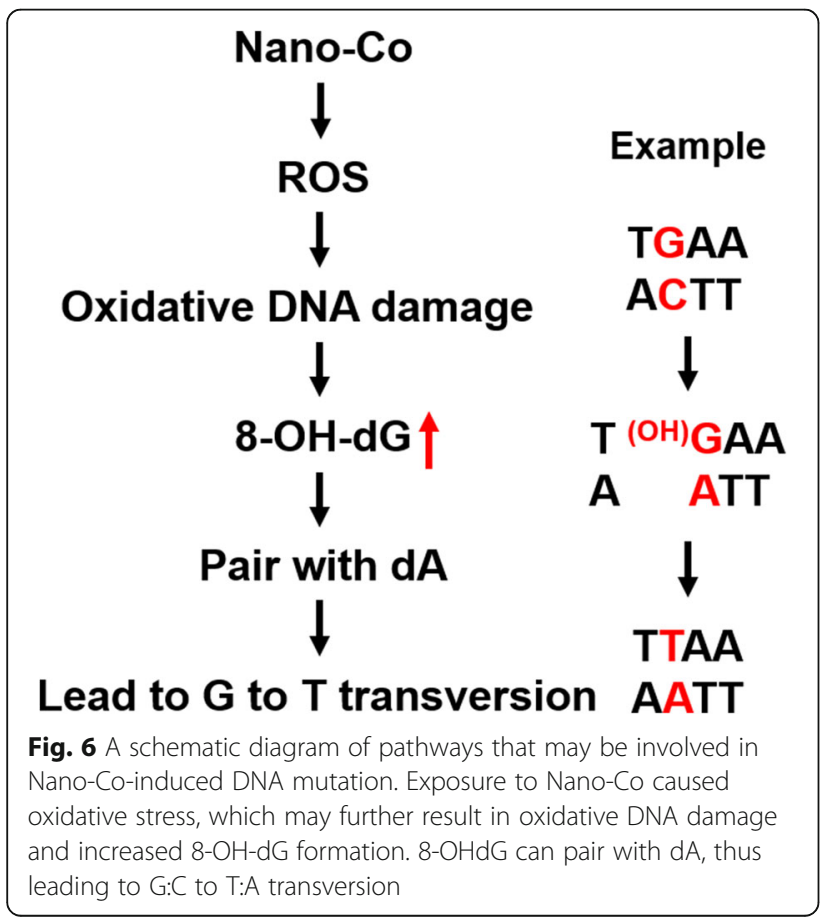

and injury, and cell proliferation, which further resulted in DNA damage and DNA mutation. Our results also showed that Nano-Co induced a much higher mutant frequency as compared to controls, and the most common mutation was $\mathrm{G}: \mathrm{C}$ to $\mathrm{T}: \mathrm{A}$ transversion, which may be explained by Nano-Co-induced increased formation of 8-OHdG. These results represent the first comprehensive in vivo genotoxicity of Nano-Co. The results provide further understanding of the potential genotoxic effects of metal nanoparticle exposure. Further studies of the mechanism of genotoxicity and application routes other than intra tracheal instillation are needed. Finally, exposure levels of Nano-Co in the working environment should be determined.

\section{Abbreviations}

6-TG: 6-thioguanine; 8-OHdG: 8-hydroxy-2'-deoxyguanosine; BALF: Bronchoalveolar lavage fluid; CXCL1/KC: Chemokine (C-X-C motif) ligand 1/keratinocyte chemoattractant; DSBs: Double-strand breaks; gpt: Guanine phosphoribosyltransferase; LDH: Lactate dehydrogenase; MF: Mutant frequency; Nano-Co: Cobalt nanoparticles; $\mathrm{Nano}-\mathrm{TiO}_{2}$ : Titanium dioxide nanoparticles; PCNA: Proliferating cell nuclear antigen; ROS: Reactive oxygen species

\section{Acknowledgements}

We thank Dr. David Tollerud for proofreading the manuscript. This work was partly supported by the NIESH/NIH (ES023693), KSEF-148-502-16-381, Kentucky Lung Cancer Research Program, and an Intramural Research Incentive Grants (50992) from Uofl to Dr. Qunwei Zhang; National Natural Science Foundation of China (81473009) and Natural Science Foundation of Fujian Province, China (2014 J01333) to Dr. Rong Wan; and the Projects of Beijing Academy of Science and Technology (PXM2016-178304-000020) to Dr. Shichuan Tang. The results were presented in part at 2016 Society of Toxicology (SOT) Annual Conference; March 13-17, 2016; New Orleans, LA.

\section{Funding}

This work was partly supported by the NIESH/NIH (ES023693), KSEF-148502-16-381, Kentucky Lung Cancer Research Program, and an Intramural Research Incentive Grants (50992) from UofL to Dr. Qunwei Zhang; National Natural Science Foundation of China (81473009) and Natural Science Foundation of Fujian Province, China (2014 J01333) to Dr. Rong Wan; and the Projects of Beijing Academy of Science and Technology (PXM2016-178304-000020) to Dr. Shichuan Tang.

Availability of data and materials

All data and materials are included in the manuscript.

\section{Authors' contributions}

$\mathrm{RW}, \mathrm{YM}, \mathrm{ZZ}$, and $\mathrm{MJ}$ carried out the preparation of and performed the experiments, and contributed to acquisition of data. Pulmonary histopathological evaluations were done by RW, YM and ZZ. RW, YM, MJ and ST analyzed the data and interpreted the results. QZ conceived and supervised the study. The manuscript was written by RW and YM and revised critically by QZ. All authors read and approved the final manuscript.

\section{Ethics approval}

The protocols and the use of animals were approved by and in accordance with the University of Louisville Animal Care and Use Committee.

Consent for publication

Not applicable.

Competing interests

The authors declare that they have no competing interests. 


\section{Publisher's Note}

Springer Nature remains neutral with regard to jurisdictional claims in published maps and institutional affiliations.

\section{Author details}

'Department of Pathology, Fujian Medical University, Fuzhou, People's Republic of China. ${ }^{2}$ Department of Environmental and Occupational Health Sciences, School of Public Health and Information Sciences, University of Louisville, 485 E. Gray Street, Louisville, KY 40202, USA. ${ }^{3}$ Seven-year Program of Clinical Medicine, Fujian Medical University, Fuzhou, People's Republic of China. ${ }^{4}$ Department of Gastroenterology, Children's Hospital, Zhejiang University, Hangzhou, People's Republic of China. ${ }^{5}$ Beijing Municipal Institute of Labor Protection, Beijing, People's Republic of China. ${ }^{6}$ Department of Preventive Medicine, Fujian Provincial Key Laboratory of Environment Factors and Cancer, School of Public Health, Fujian Medical University, Fuzhou 350122, People's Republic of China.

Received: 1 May 2017 Accepted: 11 September 2017

Published online: 18 September 2017

\section{References}

1. Bouchard LS, Anwar MS, Liu GL, Hann B, Xie ZH, Gray JW, Wang X, Pines A, Chen FF. Picomolar sensitivity MRI and photoacoustic imaging of cobalt nanoparticles. Proc Natl Acad Sci U S A. 2009;106(11):4085-9.

2. Amiri S, Shokrollahi $\mathrm{H}$. The role of cobalt ferrite magnetic nanoparticles in medical science. Mater Sci Eng C. 2013;33(1):1-8.

3. Pouponneau P, Leroux JC, Martel S. Magnetic nanoparticles encapsulated into biodegradable microparticles steered with an upgraded magnetic resonance imaging system for tumor chemoembolization. Biomaterials. 2009;30(31):6327-32.

4. Kale SN, Jadhav AD, Verma S, Koppikar SJ, Kaul-Ghanekar R, Dhole SD, Ogale $\mathrm{SB}$. Characterization of biocompatible $\mathrm{NiCO}_{2} \mathrm{O}_{4}$ nanoparticles for applications in hyperthermia and drug delivery. Nanomedicine. 2012;8(4):452-9.

5. Lu AH, Salabas EL, Schuth F. Magnetic nanoparticles: synthesis, protection, functionalization, and application. Angew Chem Int Ed. 2007;46:1222-44.

6. Monteiller C, Tran L, MacNee W, Faux S, Jones A, Miller B, Donaldson K. The pro-inflammatory effects of low-toxicity low-solubility particles, nanoparticles and fine particles, on epithelial cells in vitro: the role of surface area. Occup Environ Med. 2007;64:609-15.

7. Papageorgiou I, Brown C, Schins R, Singh S, Newson R, Davis S, Fisher J, Ingham E, Case CP. The effect of nano- and micron-sized particles of cobaltchromium alloy on human fibroblasts in vitro. Biomaterials. 2007;28:2946-58.

8. Peters K, Unger RE, Kirkpatrick CJ, Gatti AM, Monari E. Effects of nanoscale particles on endothelial cell function in vitro: studies on viability, proliferation and inflammation. J Mater Sci Mater Med. 2004;15:321-5.

9. Petrarca C, Perrone A, Verna N, VerginellivF PJ, Sabbioni E. Cobalt nanoparticles modulate cytokine in vitro release by human mononuclear cells mimicking autoimmune disease. Int J Immunopathol Pharmacol. 2006;19:11-4.

10. Ponti J, Sabbioni E, Munaro B, Broggi F, Marmorato P, Franchini F. Genotoxicity and morphological transformation induced by cobalt nanoparticles and cobalt chloride: an in vitro study in Balb/3T3 mouse fibroblasts. Mutagenesis. 2009;24:439-45.

11. Wan R, Mo Y, Feng L, Chien S, Tollerud DJ, Zhang Q. DNA damage caused by metal nanoparticles: involvement of oxidative stress and activation of ATM. Chem Res Toxicol. 2012;25(7):1402-11.

12. Totsuka Y, Higuchi T, Imai T, Nishikawa A, Nohmi T, Kato T, Masuda S, Kinae N, Hiyoshi K, Ogo S, Kawanishi M, Yagi T, Ichinose T, Fukumori N, Watanabe M, Sugimura T, Wakabayashi K. Genotoxicity of nano/microparticles in in vitro micronuclei, in vivo comet and mutation assay systems. Part Fibre Toxicol. 2009;6:23. https://doi.org/10.1186/1743-8977-6-23.

13. Totsuka Y, Ishino K, Kato T, Goto S, Tada Y, Nakae D, Watanabe M, Wakabayashi K. Magnetite nanoparticles induce genotoxicity in the lungs of mice via inflammatory response. Nanomaterials (Basel). 2014;4(1):175-88.

14. Costa M, Salnikow K, Sutherland JE, Broday L, Peng W, Zhang Q, Kluz T. The role of oxidative stress in nickel and chromate genotoxicity. Mol Cell Biochem 2004; 134/135: 265-275.

15. Lee JC, Son YO, Pratheeshkumar $P$, Shi X. Oxidative stress and metal carcinogenesis. Free Radic Biol Med. 2012;53(4):742-57.

16. Valko M, Jomova K, Rhodes CJ, Kuča K, Musílek K. Redox- and non-redoxmetal-induced formation of free radicals and their role in human disease. Arch Toxicol. 2016;90(1):1-37.
17. Scott TL, Rangaswamy S, Wicker CA, Izumi T. Repair of oxidative DNA damage and cancer: recent progress in DNA base excision repair. Antioxid Redox Signal. 2014;20(4):708-26.

18. Valko M, Rhodes CJ, Moncol J, Izakovic M, Mazur M. Free radicals, metals and antioxidants in oxidative stress-induced cancer. Chem Biol Interact. 2006:160:1-40.

19. Sage E, Shikazono N. Radiation-induced clustered DNA lesions: repair and mutagenesis. Free Radic Biol Med. 2017;107:125-35.

20. Schürkes C, Brock W, Abel J, Unfried K. Induction of 8-hydroxydeoxyguanosine by man made vitreous fibres and crocidolite asbestos administered intraperitoneally in rats. Mutat Res. 2004;553(1-2):59-65.

21. Risom L, Moller P, Loft S. Oxidative stress-induced DNA damage by particulate air pollution. Mut Res. 2005;592:119-37.

22. Albanese A, Tang PS, Chan WC. The effect of nanoparticle size, shape, and surface chemistry on biological systems. Annu Rev Biomed Eng. 2012;14:1-16

23. Medina C, Santos-Martinez MJ, Radomski A, Corrigan Ol, Radomski MW Nanoparticles: pharmacological and toxicological significance. Br J Pharmacol. 2007;150:552-8.

24. Xia T, Hamilton RF, Bonner JC, Crandall ED, Elder A, Fazlollahi F, Girtsman TA, Kim K, Mitra S, Ntim SA, Orr G, Tagmount M, Taylor AJ, Telesca D, Tolic A, Vulpe CD, Walker AJ, Wang X, Witzmann FA, Wu N, Xie Y, Zink Jl, Nel A, Holian A. Interlaboratory evaluation of in vitro cytotoxicity and inflammatory responses to engineered nanomaterials: the NIEHS Nano GO consortium. Environ Health Perspect. 2013;121(6):683-90.

25. Yameen B, Choi WI, Vilos C, Swami A, Shi J, Farokhzad OC. Insight into nanoparticle cellular uptake and intracellular targeting. J Control Release. 2014;190:485-99.

26. Singh N, Manshian B, Jenkins GJ, Griffiths SM, Williams PM, Maffeis TG, Wright CJ, Doak SH. NanoGenotoxicology: the DNA damaging potential of engineered nanomaterials. Biomaterials. 2009;30(23-24):3891-914.

27. Colognato R, Bonelli A, Ponti J, Farina M, Bergamaschi E, Sabbioni E, Migliore L. Comparative genotoxicity of cobalt nanoparticles and ions on human peripheral leukocytes in vitro. Mutagenesis. 2008;23:377-82.

28. Feng $L$, Zhang $Y$, Jiang M, Mo $Y$, Wan R, Jia Z, Tollerud DJ, Zhang X, Zhang Q. Up-regulation of Gadd45a after exposure to metal nanoparticles: the role of hypoxia inducible factor 1a. Environ Toxicol. 2015;30(4):490-9.

29. Parry MC, Bhabra G, Sood A, Machado F, Cartwright L, Saunders M, Ingham E, Newson R, Blom AW, Case CP. Thresholds for indirect DNA damage across cellular barriers for orthopaedic biomaterials. Biomaterials. 2010; 31(16):4477-83.

30. Sood A, Salih S, Roh D, Lacharme-Lora L, Parry M, Hardiman B, Keehan R, Grummer R, Winterhager E, Gokhale PJ, Andrews PW, Abbott C, Forbes K, Westwood M, Aplin JD, Ingham E, Papageorgiou I, Berry M, Liu J, Dick AD, Garland RJ, Williams N, Singh R, Simon AK, Lewis M, Ham J, Roger L, Baird DM, Crompton LA, Caldwell MA, Swalwell H, Birch-Machin M, LopezCastejon G, Randall A, Lin H, Suleiman MS, Evans WH, Newson R, Case CP. Signalling of DNA damage and cytokines across cell barriers exposed to nanoparticles depends on barrier thickness. Nat Nanotechnol. 2011;6(12): 824-33.

31. Nohmi T, Katoh M, Suzuki $H$, Matsui M, Yamada M, Watanabe M, Suzuki M, Horiya N, Ueda O, Shibuya T, Ikeda H, Sofuni T. A new transgenic mouse mutagenesis test system using Spi- and 6-thioguanine selections. Environ Mol Mutagen. 1996;28(4):465-70.

32. Nohmi T, Masumura K. Gpt delta transgenic mouse: a novel approach for molecular dissection of deletion mutations in vivo. Adv Biophys. 2004;38: 97-121.

33. Zhang Q, Kusaka Y, Sato K, Nakakuki K, Kohyama N, Donaldson K. Differences in the extent of inflammation caused by intratracheal exposure to three ultrafine metals: role of free radicals. J Toxicol Environ Health A. 1998;53(6):423-38.

34. Stopford W, Turner J, Cappellini D, Brock T. Bioaccessibility testing of cobalt compounds. J Environ Monit. 2003:5(4):675-80.

35. Serita F, Kyono H, Seki Y. Pulmonary clearance and lesions in rats after a single inhalation of ultrafine metallic nickel at dose levels comparable to the threshold limit value. Ind Health. 1999;37(4):353-63.

36. Zhang Q, Kusaka Y, Donaldson K. Comparative rat pulmonary responses caused by exposure to standard cobalt and ultrafine cobalt. J Occup Health. 2000:42:179-84

37. Zhang Q, Kusaka Y, Zhu X, Sato K, Mo Y, Kluz T, Donaldson K. Comparative toxicity of standard nickel and ultrafine nickel in lung after intratracheal instillation. J Occup Health. 2003:45:20-32. 
38. Driscoll KE, Costa DL, Hatch G, Henderson R, Oberdorster G, Salem H, et al. Intratracheal instillation as an exposure technique for the evaluation of respiratory tract toxicity: uses and limitations. Toxicol Sci. 2000;55(1):24-35.

39. Seiler F, Rehn B, Rehn S, Hermann M, Bruch J. Quartz exposure of the rat lung leads to a linear dose response in inflammation but not in oxidative DNA damage and mutagenicity. Am J Respir Cell Mol Biol. 2001;24(4):492-8.

40. Nohmi T, Suzuki T, Masumura K. Recent advances in the protocols of transgenic mouse mutation assays. Mutat Res. 2000;455:191-215.

41. Horiguchi M, Masumura K, Ikehata H, Ono T, Kanke Y, Sofuni T, Nohmi T. UVB-induced gpt mutations in the skin of gpt delta transgenic mice. Environ Mol Mutagen. 1999;34(2-3):72-9.

42. Masumura K, Totsuka Y, Wakabayashi K, Nohmi T. Potent genotoxicity of aminophenylnorharman, formed from nonmutagenic norharman and aniline, in the liver of gpt delta transgenic mouse. Carcinogenesis. 2003;24(12):1985-93.

43. Mo Y, Feinstein Sl, Manevich Y, Zhang Q, Lu L, Ho YS, Fisher AB. 1-Cys peroxiredoxin knock-out mice express mRNA but not protein for a highly related intronless gene. FEBS Lett. 2003;55(2):192-8.

44. Mah LJ, El-Osta A, Karagiannis TC. gammaH2AX: a sensitive molecular marker of DNA damage and repair. Leukemia. 2010;24(4):679-86.

45. Sedelnikova OA, Pilch DR, Redon C, Bonner WM. Histone H2AX in DNA damage and repair. Cancer Biol Ther. 2003;2(3):233-5.

46. Behl M, Stout MD, Herbert RA, Dill JA, Baker GL, Hayden BK, Roycroft JH, Bucher JR, Hooth MJ. Comparative toxicity and carcinogenicity of soluble and insoluble cobalt compounds. Toxicology. 2015;333:195-205.

47. IARC, 2006. IARC cobalt in hard metals and cobalt sulfate, gallium arsenide, indium phosphide and vanadium pentoxide IARC Monogr. Eval. Carcinog. Risks humans, 86. Lyon; 2006.

48. (CAS No. 7440-48-4) in F344/N Rats and B6C3F1/N Mice and Toxicology and Carcinogenesis Studies of Cobalt Metal (CAS No. 7440-48-4) in F344/N Rats and B6C3F1/N Mice (Inhalation Studies). Peer Review Draft. Technical Report Series No. 581. NIH Publication No. 14-5923 U.S. Department of Health and Human Services, Public Health Service, National Institutes of Health, Research Triangle Park; 2014.

49. NTP, 2016, NTP: Report on Carcinogens. Monograph on Cobalt and Cobalt Compounds that Release Cobalt lons in Vivo. Office of the Report on Carcinogens. Division of the National Toxicology Program. National Institute of Environmental Health Sciences. Research Triangle Park: U.S. Department of Health and Human Services, National Institutes of Health; 2016.

50. Alarifi S, Ali D, Y AO, Ahamed M, Siddiqui MA, Al-Khedhairy AA. Oxidative stress contributes to cobalt oxide nanoparticles-induced cytotoxicity and DNA damage in human hepatocarcinoma cells. Int J Nanomedicine 2013;8:189-99.

51. Annangi B, Bach J, Vales G, Rubio L, Marcos R, Hernández A. Long-term exposures to low doses of cobalt nanoparticles induce cell transformation enhanced by oxidative damage. Nanotoxicology. 2015;9(2):138-47.

52. Sabbioni E, Fortaner S, Farina M, Del Torchio R, Olivato I, Petrarca C, Bernardini G, Mariani-Costantini R, Perconti S, Di Giampaolo L, Gornati R, Di Gioacchino M. Cytotoxicity and morphological transforming potential of cobalt nanoparticles, microparticles and ions in Balb/3T3 mouse fibroblasts: an in vitro model. Nanotoxicology. 2014;8(4):455-64.

53. Hwang DW, Lee DS, Kim S. Gene expression profiles for genotoxic effects of silica-free and silica-coated cobalt ferrite nanoparticles. J Nucl Med. 2012; 53(1):106-12.

54. Current Intelligence Bulletin 63: Occupational Exposure to Titanium Dioxide. DHHS (NIOSH) Publication Number 2011-160. https://www.cdc.gov/niosh/ docs/2011-160/pdfs/2011-160.pdf

55. Saini Y, Kim KY, Lewandowski R, Bramble LA, Harkema JR, Lapres JJ. Role of hypoxia-inducible factor 1 \{alpha\} in modulating cobalt-induced lung inflammation. Am J Physiol Lung Cell Mol Physiol. 2010;298(2):L139-47.

56. Proper SP, Saini Y, Greenwood KK, Bramble LA, Downing NJ, Harkema JR, Lapres JJ. Loss of hypoxia-inducible factor 2 alpha in the lung alveolar epithelium of mice leads to enhanced eosinophilic inflammation in cobaltinduced lung injury. Toxicol Sci. 2014;137(2):447-57.

57. Sisler JD, Li R, McKinney W, Mercer RR, Ji Z, Xia T, Wang X, Shaffer J, Orandle M, Mihalchik AL, Battelli L, Chen BT, Wolfarth M, Andrew ME, SchweglerBerry D, Porter DW, Castranova V, Nel A, Qian Y. Differential pulmonary effects of $\mathrm{CoO}$ and $\mathrm{La}_{2} \mathrm{O}_{3}$ metal oxide nanoparticle responses during aerosolized inhalation in mice. Part Fibre Toxicol. 2016;13(1):42. https://doi.org/10.1186/s12989-016-0155-3.

58. Phillips JI, Green FY, Davies JC, Murray J. Pulmonary and systemic toxicity following exposure to nickel nanoparticles. Am J Ind Med. 2010; 53(8):763-7.
59. Donaldson K, Brown GM. Bronchoalveolar lavage in the assessment of the cellular response to fiber exposure. In: Warheit D, editor. Fiber toxicology. Florida: Academic Press; 1993. p. 117-38.

60. Henderson RF. Use of bronchoalveolar lavage to detect lung damage. Environ Health Pers. 1984;56:115-29.

61. Donaldson K, Bolton RE, Jones A, Brown GM, Robertson MD, Slight J, Cowie $H$, Davis JM. Kinetics of the bronchoalveolar leucocyte response in rats during exposure to equal airborne mass concentrations of quartz, chrysotile asbestos, or titanium dioxide. Thorax. 1988;43(7):525-33.

62. Donaldson K, Brown GM, Brown DM, Slight J, Li XY. Epithelial and extracellular matrix injury in quartz-inflamed lung: role of the alveolar macrophage. Environ Health Perspect. 1992;97:221-4.

63. Grommes J, Soehnlein O. Contribution of neutrophils to acute lung injury. Mol Med. 2011 Mar-Apr;17(3-4):293-307.

64. Kyono H, Kusaka Y, Homma K, Kubota H, Endo-Ichikawa Y. Reversible lung lesions in rats due to short-term exposure to ultrafine cobalt particles. Ind Health. 1992;30(3-4):103-18.

65. Ibuki Y, Toyooka T. Evaluation of chemical phototoxicity, focusing on phosphorylated histone H2AX. J Radiat Res. 2015;56(2):220-8.

66. Albino AP, Jorgensen ED, Rainey P, Gillman G, Clark TJ, Gietl D, Zhao H, Traganos F, Darzynkiewicz Z. gammaH2AX: a potential DNA damage response biomarker for assessing toxicological risk of tobacco products. Mutat Res. 2009;678(1):43-52.

67. Toyooka T, Ibuki Y. Cigarette sidestream smoke induces phosphorylated histone H2AX. Mutat Res. 2009;676(1-2):34-40.

68. Karlsson HL, Gliga AR, Calléja FM, Gonçalves CS, Wallinder IO, Vrieling H, Fadeel B, Hendriks G. Mechanism-based genotoxicity screening of metal oxide nanoparticles using the ToxTracker panel of reporter cell lines. Part Fibre Toxicol. 2014;11:41. https://doi.org/10.1186/s12989-014-0041-9.

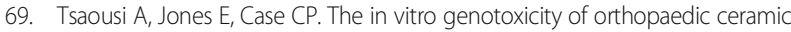
$\left(\mathrm{Al}_{2} \mathrm{O}_{3}\right.$ ) and metal (CoCr alloy) particles. Mutat Res. 2010;697(1-2):1-9.

70. Borm PJ, Driscoll K. Particles, inflammation and respiratory tract carcinogenesis. Toxicol Lett. 1996;88(1-3):109-13.

71. Shacter E, Weitzman SA. Chronic inflammation and cancer. Oncology (Williston Park). 2002;16(2):217-26. 229; discussion 230-232.

72. Gerdes J, Lemke H, Baisch H, Wacker HH, Schwab U, Stein H. Cell cycle analysis of a cell proliferation-associated human nuclear antigen defined by the monoclonal antibody Ki-67. J Immunol. 1984;133(4):1710-5.

73. Gerdes J. Ki-67 and other proliferation markers useful for immunohistological diagnostic and prognostic evaluations in human malignancies. Semin Cancer Biol. 1990;1(3):199-206.

74. Kill IR. Localisation of the Ki-67 antigen within the nucleolus. Evidence for a fibrillarin-deficient region of the dense fibrillar component. J Cell Sci. 1996; 109(Pt 6):1253-63.

75. Gerdes J, Schwab U, Lemke H, Stein H. Production of a mouse monoclonal antibody reactive with a human nuclear antigen associated with cell proliferation. Int J Cancer. 1983;31(1):13-20.

76. Verheijen $R$, Kuijpers $H J$, van Driel $R$, Beck $J$, van Dierendonck JH, Brakenhoff GJ, Ramaekers FC. Ki-67 detects a nuclear matrix-associated proliferation-related antigen. II. Localization in mitotic cells and association with chromosomes. J Cell Sci. 1989;92(Pt 4):531-40.

77. Haneda H, Katabami M, Miyamoto H, Isobe H, Shimizu T, Ishiguro A, Moriuti T, Takasaki Y, Kawakami Y. The relationship of the proliferating cell nuclear antigen protein to cis-diamminedichloroplatinum (II) resistance of a murine leukemia cell line P388/CDDP. Oncology. 1991;48(3):234-8.

78. Choe KN, Moldovan GL. Forging ahead through darkness: PCNA, still the principal conductor at the replication fork. Mol Cell. 2017;65(3):380-92.

79. Wood ML, Dizdaroglu M, Gajewski E, Essigmann JM. Mechanistic studies of ionizing radiation and oxidative mutagenesis: genetic effects of a single 8hydroxyguanine (7-hydro-8-oxoguanine) residue inserted at a unique site in a viral genome. Biochemistry. 1990;29(30):7024-32.

80. Ballmaier D, Epe B. Oxidative DNA damage induced by potassium bromate under cell-free conditions and in mammalian cells. Carcinogenesis. 1995; 16(2):335-42.

81. Halliwell B, Chirico S. Lipid peroxidation: its mechanism, measurement, and significance. Am J Clin Nutr. 1993;57(5 Suppl):715S-724S. discussion 724S-725S.

82. Dizdaroglu M, Nackerdien Z, Chao BC, Gajewski E, Rao G. Chemical nature of in vivo DNA base damage in hydrogen peroxide-treated mammalian cells. Arch Biochem Biophys. 1991;285(2):388-90.

83. Knaapen AM, Borm PJ, Albrecht C, Schins RP. Inhaled particles and lung cancer. Part A: Mechanisms Int J Cancer. 2004;109(6):799-809. 
84. Manke A, Wang L, Rojanasakul Y. Mechanisms of nanoparticle-induced oxidative stress and toxicity. Biomed Res Int. 2013;2013:942916. https://doi. org/10.1155/2013/942916.

85. Moche $H_{1}$ Chevalier D, Vezin $H_{1}$ Claude N, Lorge E, Nesslany F. Genotoxicity of tungsten carbide-cobalt (WC-co) nanoparticles in vitro: mechanisms-ofaction studies. Mutat Res Genet Toxicol Environ Mutagen. 2015;779:15-22.

Submit your next manuscript to BioMed Central and we will help you at every step:

- We accept pre-submission inquiries

- Our selector tool helps you to find the most relevant journal

- We provide round the clock customer support

- Convenient online submission

- Thorough peer review

- Inclusion in PubMed and all major indexing services

- Maximum visibility for your research

Submit your manuscript at www.biomedcentral.com/submit 